Ilmu Ladunni Dalam Perspektif Pendidikan Islam;

Telaah Atas Pemikiran Abu Hamid Al-Ghazali

\title{
ILMU LADUNNI DALAM PERSPEKTIF PENDIDIKAN ISLAM; TELAAH ATAS PEMIKIRAN ABU HAMID AL-GHAZALI
}

\author{
Yulianto \\ Program Studi Pendidikan Agama Islam Universitas Islam Raden Rahmat Kepanjen Malang
}

\begin{abstract}
As a knowledge that is derived from eternal ray of light (Transcendental God) into majazi light (with different potentials) included in four human's spirituality: mind, soul, spirit, and heart, Ladunni is an the innate and internal part of human being that wait to be re-actualized. Therefore, the right perspective about the birth of Ladunni is it becomes real because of the human's effort and emanation of God's gift. Since the mediator of Ladunni actually has been stored in various potentials that belong to human beings since they were born, the role of education is to activate those innate abilities from potentials into the real human's identity. An actualization of human's potential which is systematized in the learning process is called as humanistic curriculum. The objectives of this research were (1) determining the essence of Ladunni, (2) determining the method that was offered by Abu Hamid al-Ghazali to obtain the knowledge of Ladunni, and (3) determining the contribution of the knowledge of Ladunni towards Islamic education. This research was a library research with qualitative-descriptive approach. It used documentation as the data collection, and content analysis to explore various data from the books written by Abu Hamid al-Ghazali which were then composed into systematic narration. The result of this research are (1) Ladunni is a product of actualization from various human's potential which has been integrated in human's spirituality; (2) everybody is able to obtain the knowledge of Ladunni; (3) two methods which are used to obtain the knowledge of Ladunni are internal and external methods. The coverage of internal method is learning, thinking, riyädatun nafsi, mujāhadah also being patient, and the external method is by consuming halal food; (4) the access of Ladunni is also divided into external and internal, where external access is mirrored through a knowledge access called as divine revelation and divine inspiration while internal access can be seen from human's spirituality; (5) humanistic curriculum is the most suitable curriculum in formal education to reflect the knowledge of Ladunni.
\end{abstract}

Keyword: Ladunni in the Perspective of Islamic Education

\section{Pendahuluan}

Islam adalah agama yang sangat menjunjung tinggi pendidikan dan ilmu

pengetaahuan. Hal ini tercermin dalam tiga dimensi, yaitu: (1) pendidikan islami; (2) 


\section{Yulianto}

pendidikan agama Islam; dan (3) pendidikan dalam Islam. ${ }^{1}$ Oleh karena itulah dalam pendidikan Islam dimensi iman, Islam, dan ihsan sebagai tiga fondasi agama Islam harus terintegrasikan secara komprehensif dengan ilmu pengetahuan tanpa ada dikotomi di antara salah satu pihak. ${ }^{2}$ Meminjam istilah az-Zarnudji, tentu kita tidak ingin adanya pohon ilmu tanpa buah (ilmu bila samrah). ${ }^{3}$ Penekanan kepada salah satunya dengan mengabaikan yang lainnya hanya akan menimbulkan berbagai kepincangan dalam kehidupan sebagaimana terjadi di Barat sepanjang abad 18, 19, dan 20 Masehi. $^{4}$

Alasan paling mendasar dari pernyataan di atas adalah karena iman, Islam, dan ihsan adalah tiga fondasi utama syariat Muhammad SAW, yang dari ketiganya seluruh bangunan syariat menjadi komprehensip. ${ }^{5}$ Dari term iman lahir disiplin ilmu teologi, dari term Islam lahir ilmu fikih, dan dari term ihsan lahir ilmu tasawuf. ${ }^{6}$

\footnotetext{
${ }^{1}$ Tiga dimensi tipologi pendidikan Islam tersebut adalah (1) Pendidikan Islami atau Pendidikan menurut Islam adalah sebuh konsep, pemikiran, atau teori pendidikan yang dipahami dan dikembangkan dari ajaran agama Islam, yang bersumber dari al-Quran dan al-Sunnah; (2) Pendidikan keislaman atau Pendidikan Agama Islam adalah suatu kegiatan yang bertujuan meng-instal nilai-nilai ajaran Islam agar menjadi madzhab berfikir, pandangan sekaligus sikap hidup; dan (3) Pendidikan dalam Islam adalah sebuah proses dan praktek pendidikan yang pernah terjadi dan diusahakan dalam sejarah umat Islam. Dengan pengertian lain, Pendidikan Islam adalah berbagai macam pendidikan yang pernah dikembangkan oleh para pakar pendidikan Islam dari generasi ke generasi. Lihat Khozin, Jejak-Jejak Pendidikan Islam di Indonesia Rekonstruksi Sejarah Untuk Aksi (Malang: UMM Press, 2006), 18. 2 Abuddin Nata dan dkk, Integrasi ilmu Agama \& Ilmu Umum (Jakarta: Raja Grafindo Persada, 2005), 186.

${ }^{3}$ Az-Zarnuji memiliki nama lengkap yaitu Burhanuddin al-Islam Az-Zarnuji, almarhum hidup pada akhir ke-12 dan awal abad 13 yang kira-kira tahun 591-640 H/1195-1243 M). Pada zamannya perkembangan Pendidikan Islam masih berpusat di kota Bukhara dan Samarkan, pusat-pusat bergulirnya proses pendidikan waktu itu masih memakai Mesjid-mesjid sebagai lembaga institusi pendidikan. Lihat Abuddin Nata, Pemikiran Para tokoh Pendidikan Islam Seri Kajian Filsafat Pendidikan Islam (Jakarta: Raja Grafindo Persada, 1988), 41; Zuhairini, Sejarah Penddikan Islam (Jakarta: Bumi Aksara, 1992), 7.

4 Ilyas Ismail, True Islam: Moral, Intelektual, Spritual (Jakarta: Mitra Wacana Media, 2013), V.

${ }^{5}$ Abi 'Abdillah Ibn Isma'il Bukhari, Shahīhu-l-Bukhāri (Beirut: Dār al-Kutub al-Ilmiyah, 2005), 31.

${ }^{6}$ Muhammad Salikhin, Filsafat dan Metafisika dalam Islam (Jakarta: Buku Kita, 2008), 221-28.
} 


\section{Ilmu Ladunni Dalam Perspektif Pendidikan Islam; \\ Telaah Atas Pemikiran Abu Hamid Al-Ghazali}

Khusus dalam disiplin ilmu tasawuf, pemahaman komprehensif seputar akidah dan syariah, aplikasi ilmiyah, dan ikhlas beramal adalah tiga pilar utama bangunan tegaknya tasawuf, baik dalam dimensi teori atau aplikasi.7

Dalam ranah terminologi, disiplin ilmu tasawuf memiliki banyak istilah yang terkadang sulit dimengerti oleh komunitas di luar mereka. Kesukaran yang terkadang berujung kepada kesalahpahaman dan pengingkaran terhadap tasawuf itu sendiri. Di antara istilah ilmu tasawuf yang terus menjadi sebab kesalahpahaman dan pengingkaran terhadap tasawuf itu sendiri adalah istilah ilmu ladunni. Para pemikir dan teolog Islam masih silang pendapat mengenai; pertama, orang yang mendapatkan ilmu ladunni, dan kedua, metode memperoleh ilmu ladunni.

Mengenai orang yang bisa memperoleh ilmu ladunni, para sarjana Islam terpecah menjadi dua kelompok, yaitu: pertama, kelompok ekstrim yang diwakili oleh kaum Wahabi dan Syi'ah dan kedua, kelompok moderat. Kaum Wahabi berpendapat bahwa ilmu ladunni adalah ilmu yang hanya bisa dimiliki oleh para nabi dan rasul. ${ }^{8}$ Sedangkan kelompok Sy'iah berpendapat bahwa ilmu ladunni adalah ilmu yang hanya bisa dimiliki oleh para nabi, rasul, dan imam golongan Syi'ah. Sedangkan kelompok moderat, yang diwakili oleh kaum sunni - khususnya para pengamal tasawuf falsafi seperti Abu Hamid al-Ghazali, berpendapat bahwa ilmu ladunni bisa diperoleh oleh semua manusia. ${ }^{9}$

\footnotetext{
7 Abdul Gholib Ahmad Isa, Mafhūmut Tasawwuf (Beirut: Dār al-Jīl, 1992), 14.

${ }^{8}$ Ihsan Utaybi, Arsip Multaqā ahlil hadis (Maktabah Syamilah al-Ișdar aś-Ṡani, n.d.), 991.

${ }^{9}$ Abu Hamid al-Ghazāli, Majmū' 'ah Rasāil; ar-Risālah Alladuniyah (Maktabah at-TaufĪqiyyah, n.d.), 252.
} 


\section{Yulianto}

Sedangkan dalam hal cara mendapatkan ilmu ladunni, para intelek dan sarjanawan juga terbagi menjadi tiga kelompok, yaitu; pertama, kelompok filsuf. Kedua, kelompok sufi, dan ketiga, kelompok filsuf-sufi. Dalam pandangan kelompok pertama, ilmu ladunni dapat diperoleh melalui aktifasi akal melalui metode logik. Istilah ilmu ladunni lebih dikenal dengan istilah al-hadas. Dalam wacana filsafat alhadas modern, nama Henri Louis Bergson (W. 1941 M) ${ }^{10}$ adalah nama seorang filsuf yang paling berkompeten. ${ }^{11}$ Sebagai metode logik dalam memperoleh ilmu, al-hadas menggunakan saluran ilmu berupa akal.12

Berbeda dengan kelompok pertama, kelompok sufi berada dalam mainstrem yang secara diametral berseberangan dengan kelompok filsuf. Menurut mereka, metode untuk mencapai ilmu ladunni adalah melalui metode intuitif. ${ }^{13}$ Ilmu ladunni dapat diperoleh melalui proses (1) penyucian hati dari kerusakan yang bersumber dari keyakinan (i'tiqād), karakkter (akhlāk), perbuatan, dan harta benda; dan (2) mencintai orang lain sebagaimana mencintai dirinya sendiri (ìs $\bar{a} r$ wa mahabbah). ${ }^{14}$

\footnotetext{
${ }^{10}$ Henri Louis Bergson (lahir di Paris, Perancis, 18 Oktober 1859 - meninggal di Paris, Perancis, 4 Januari 1941 pada umur 81 tahun) merupakan seorang filsuf Perancis yang berpengaruh besar terutama pada awal abad ke 20. Ia lahir dari seorang ibu berdarah Inggris dan seorang ayah berdarah Yahudi Polandia. Sebagian besar masa produktifnya dihabiskannya sebagai seorang dosen filsafat dan seorang penulis. Bergson pernah memperoleh nobel untuk sastra pada 1927. Pada tahun-tahun terakhir masa hidupnya, pemikiran Bergson mulai bergeser ke arah religius. Ia bergabung dalam Gereja Katolik Roma tidak lama sebelum kematiannya. Walaupun demikian, hal ini sengaja ditunda dan dirahasiakan, karena ia tidak ingin memberi kesan mengkhianati bangsa Yahudi, sewaktu Perancis masih ada dalam pendudukan Jerman. Lihat ar-Royce Syarel Helwa, Mausū 'ah A'lāmul Falsafah (Beirut: Dār al-Kutub al-Ilmiyah, 1992), 214.

${ }_{11}$ Abdur Rahman bin Zaid az-Zubaidi, Mașādirul Ma 'rifah Fi al-Fiker ad-Dini wa al-Falsafi (Riyadh: Maktabah al-Muayyad, 1992), 267.

12 Raji Abdul Hamid, Naz̄āriyah Ma 'rifat Bainal Qur'ān wal Falsafah (Riyadh: Maktabah al-Muayyad, 1992), 670-71.

${ }^{13}$ Hamid, Nazāriyah Ma'rifat Bainal Qur'ān wal Falsafah, 672.

${ }^{14}$ Rosidin, Epistimologi Pendidikan Islam (Yogyakarta: Diandra Kreatif, 2013), 217.
} 


\section{Ilmu Ladunni Dalam Perspektif Pendidikan Islam; Telaah Atas Pemikiran Abu Hamid Al-Ghazali}

Jika para filsuf berpendapat bahwa al-hadas hanya bisa diperoleh lewat aktifasi akal melalui metode logik, sedangkan para sufi berpendapat bahwa metode untuk mendapatkan ilmu ladunni adalah melalui metode intuitif, maka Abu Hamid alGhazali sebagai seorang tokoh tasawuf sekaligus filsafat merekonsiliasikan kedua pendapat sebelumnya dengan menjadikan saluran ilmu ladunni berasal dari dua saluran sekaligus, yaitu pertama, akal melalui metode logik dan kedua, olah spiritual serta praktik syariat ('amaliyah syar 'iyah) sebagai jalur intuitif. ${ }^{15}$

Pembahasan tentang ilmu ladunni sangat inheren dengan pendidikan Islam karena pendidikan Islam adalah salah satu pendidikan yang menjadikan intuisi sebagai metode memperoleh ilmu. ${ }^{16}$ Karena itu penambahan term Islam ${ }^{17}$ dalam terminologi pendidikan Islam yang secara otomatis memberikan pengertian adanya pembatasan kerangka berpikir tentang konsep suatu pendidikan, yang dalam konteks ini dibatasi dengan ajaran-ajaran Islam ${ }^{18}$ seharusnya juga memberikan pemahaman tentang sebuah model pembelajaran dan metodologi pengajaran yang bersumber dari Dzat Yang Maha Mendidik, Memperhatikan, dan Melindungi19 ${ }^{19}$ rRabb) sebagaimana arti dari kata Islam itu sendiri. ${ }^{20}$

\footnotetext{
${ }^{15}$ Hamid, Nazāriyah Ma'rifat Bainal Qur'ān wal Falsafah, 678.

${ }^{16}$ Mujammil Qomar, Epistemologi Pendidikan Islam: Dari Metode Rasional Hingga Metode Kritik (Jakarta: Erlangga, 2006), 109-10.

${ }_{17}$ Secara etimologis (asal-usul kata, lughawi) kata "Islam" berasal dari bahasa Arab: salima yang artinya (1) selamat, (2) tunduk. Pengertian kedua tersebut senada dengan definisi al-Jurjani yang memberikan arti Islam sebagai kerendahan hati dan diri yang disertai proses ittiba' kepada ajaran Rasulillah SAW. Lihat Ahmad bin Muhammad al-Fayumi, al-Misbāh al-Munīr (Qohiroh: Dar al-Hadits, 2000), 173; Ali Muhammad al-Jurjani, at-Ta 'rifät (Jakarta: al-Harāmain, n.d.), 24.

18 Ahmad Tafsir, Ilmu Pendidikan Dalam Perspektif Islam (Bandung: Remaja Rosdakarya, 2011), 24.

${ }^{19}$ Sayyid Qutub, Fi Zilal al-Qur'ān, vol. VI (Beirut: Dār as-Syurūq, 1992), 4010.

20 al-Fayumi, al-Misbāh al-Munìr, 173.
} 


\section{Yulianto}

Tujuan utama pendidikan Islam adalah membentuk individu berkepribadian utuh jasmani dan rohani yang mampu hidup dengan wajar dan normal berdasarkan ketakwaannya kepada Allah SWT (insān kāmil). ${ }^{21}$ Namun, dalam era modern ini ranah pendekatan, metode, dan teknik pembelajaran pendidikan Islam masih terkesan mengenyampingkan ranah afektif yang di dalamnya terkandung proses pembersihan jiwa (tazkiyatun Nufüs) sebagai media penanaman akhlak sekaligus kunci utama ilmu hikmah.

Pembelajaran yang hanya menjadikan sumber ilmu berasal dari manusia, baik berupa peserta didik atau pendidik, memiliki dampak negatif berupa semakin gersangnya spiritual peserta didik dari nilai-nilai ilähiyah dalam berbagai disiplin ilmu yang dipelajarinya. Jelas implikasi tersebut sangat bertentangan dengan tujuan pendidikan Islam yang bermaksud menciptakan manusia paripurna (insān kāmil) dalam setiap jenjang pendidikan berdasarkan keimanan dan ketakwaan kepada Dzat Yang Maha Mengetahui. ${ }^{22}$

Tulisan ini bertujuan untuk mencari problem solving mengenai masih terkesampingkannya hal-hal berikut; pertama, sumber ilmu dari Dzat Yang Maha Transedental (Tuhan), yang berimplikasi terhadap dekontruksi metode pembelajaran pendidikan Islam ${ }^{23}$ hanya terlalu fokus pada pendidik atau peserta didik; kedua, alat

\footnotetext{
${ }^{21}$ Nur Uhbiyati, Ilmu Pendidikan Islam (Bandung: Pustaka Setia, 1999), 41.

22 Uhbiyati, Ilmu Pendidikan Islam, 41.

${ }^{23}$ Penggunaan kata Pendidikan Agama Islam dalam judul di atas menyesuaikan dengan tipologi pendidikan Islam yang diketengahkan Khozin mengutip Muhaimin, yaitu (1) Pendidikan Islami atau Pendidikan menurut Islam adalah sebuh konsep, pemikiran, atau teori pendidikan yang dipahami dan dikembangkan dari ajaran agama Islam, yang bersumber dari al-Quran dan al-Sunnah; (2) Pendidikan
} 


\section{Ilmu Ladunni Dalam Perspektif Pendidikan Islam; Telaah Atas Pemikiran Abu Hamid Al-Ghazali}

atau saluran ilmu berupa intuisi dan ilham sebagai ciri khas pendidikan Islam di lembaga formal yang terintegrasikan sebagai metode pembelajaran sekaligus budaya keagamaan (culture of religious); dan ketiga, minimnya referensi khusus yang membahas ilmu ladunni.

Pemikiran Abu Hamid al-Ghazali dipilih sebagai fokus kajian tentang konsep ilmu ladunni bukan karena kesakralan ketokohan atau karena terjebak dalam ortodoksi pemikiran keagamaan (taqdīs al-afkārud dìn) an sich, namun lebih karena beberapa pertimbangan lain, yaitu: pertama, dari perspektif pendidikan, Abu Hamid al-Ghazali memiliki banyak karya tulis yang di dalamnya memuat beberapa komponen pendidikan Islam seperti Ihya' Ulümuddīn, Ayyuhal walad, dan Mursyidul $A \min ^{24}$ yang secara riil banyak menjadi bacaan wajib dikalangan tradisionalis dan sebagian pos-modernis. Kedua, dari perspektif filsafat pendidikan, Abu Hamid alGhazali memiliki landasan filosofis berbasis filsafat paripatetik dalam penciptaan ${ }^{25}$ dan parenial-essensialis kontekstual-falsifikatif26 dalam pendidikan sebagaimana

\footnotetext{
keislaman atau Pendidikan Agama Islam adalah suatu kegiatan yang bertujuan meng-instal nilai-nilai ajaran Islam agar menjadi madzhab berfikir, pandangan sekaligus sikap hidup; dan (3) Pendidikan dalam Islam adalah sebuah proses dan praktek pendidikan yang pernah terjadi dan diusahakan dalam sejarah umat Islam. Dengan pengertian lain, Pendidikan Islam adalah berbagai macam pendidikan yang pernah dikembangkan oleh para pakar pendidikan Islam dari generasi ke generasi. Lihat Khozin, Jejak-Jejak Pendidikan Islam di Indonesia Rekonstruksi Sejarah Untuk Aksi, 18.

${ }^{24}$ Ahmad Barizi, Pendidikan Integratif (Malang: UIN Maliki Press, 2011), 234.

${ }_{25}$ Paripatetik (masyā'iyah) adalah sebuah istilah yang diadopsi dari bahasa Yunani paripatein yang berarti berjalan dengan berkeliling. kata tersebut secara eksplisit juga meujuk kepada serambi gedung olah raga di Athena, yang biasa digunakan Aristoteles mengajar sambil berjalan-jalan. Dalam tradisi Islam, term tersebut terkenal dengan nama masya'iyah yang berarti melangkahkan kaki dari satu tempat ketempat yang lain. Term tersebut secara implisit menunjukan metode pengajaran Aristoteles dalam menggembleng siswa-siswanya. Lihat Majid Fakhri, "al-Masyā'iyah al-Qadìmah," dalam alMausū'atul Falsafiyatul Arābiyah, vol. II (Ma'had al-Inma al-Arābiyah, 1998), 1274.

${ }^{26}$ Tipologi parenial-essensialis kontekstual-falsifikatif adalah sebuah filsafat pendidikan Islam yang berusaha untuk selalu bersikap moderat antara kembali ke masa lalu dan masa sekarang lewat
} 


\section{Yulianto}

termaktub dalam beberapa karyanya seperti Misykātul Anwār, Munqiż Minaḍ Dhalāl, dan Maqhāshidul Falāsifah; dan ketiga, dari segi metodologi (manhaj) pemikiran, Abu Hamid al-Ghazali termasuk ulama beraliran sunni yang telah mampu merekonsiliasi dengan begitu harmonis antara ketiga fondasi pokok syariat Muhammad SAW, yaitu Islam (fikih), Iman (teologi), dan Ihsan (tasawuf). Sebuah metodologi yang secara aplikatif menjadi manhaj para intelektual muslim Sunni, khususnya di Indonesia terlebih kaum muslim tradisionalis. ${ }^{27}$

\section{Pengertian, Saluran (Ṭarīqoh), dan Sumber (Mașdār) Ilmu Ladunni}

Definisi mengenai ilmu Ladunni dapat dirangkum dalam kalimat berikut;

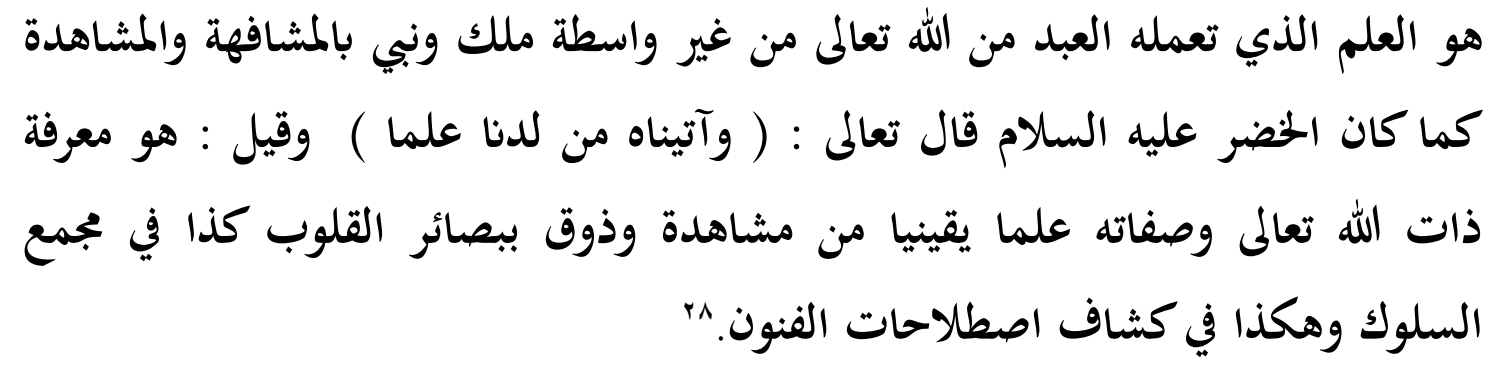

Artinya: Ilmu Ladunni adalah ilmu yang diperoleh seorang hamba dari Allah SWT tanpa perantara malaikat atau nabi melalui firman (musyāfahah) atau penyaksian (musyāhadah) sebagaimana firman Allah SWT :"dan Kami

kontekstualisasi dan uji falsifikasi dalam mengembangkan wawasan-wawasan pendidikan Islam. dalam perspektif filsafat ini, fungsi utama pendidikan Islam adalah untuk mempertahankan dan melestarikan nilai-nilai, baik yang terdapat dalam idealitas ilahiyah atau ketika sudah ter-instalisasi dalam realitas insaniyah -meminjam istilah Faisal Ismail - sekaligus menumbuh kembangkannya dalam konteks perkembangan ilmu pengetahuan, teknologi, dan perubahan sosial. Lihat Muhaimin, Pengembangan Kurikulum Pendidikan Agama Islam (Jakarta: Raja Grafindo Persada, 2009), 104.

${ }^{27}$ Kesimpulan di atas secara eksplisit mendapatkan justifikasi dari praktek keberagamaan para penganut Islam Tradisionalis di Indonesia khususnya Nahdlatul Ulama, yang menjadikan pemikiran Abu Hamid al-Ghozali sebagai reference utama sekaligus madzhab dalam bertasawuf. Lihat A. Wahid Zaini, Dunia Pemikiran Kaum Santri (Yogyakarta: LKPSM, 1999), 39-41.

${ }^{28}$ Sadik bin Hasan al-Qanuji Qanuji Abajadul 'Ulūmil Wasyīl Marqūm Fī Bayāni Ahwālil 'Ulūm (Bairut: Dārul Kutubil Ilmiyah, 1978), Abajadul 'Ulūmil Wasyīl Marqūm F̄̄ Bayāni Ahwālil 'Ulūm (Beirut: Dārul Kutub al-Ilmiyah, 1978), 469. 


\section{Ilmu Ladunni Dalam Perspektif Pendidikan Islam; Telaah Atas Pemikiran Abu Hamid Al-Ghazali}

memberikan padanya (Khidir as) ilmu ladunni". Dalam pengertian lain, ilmu ladunni adalah pengetahuan tentang dzat dan sifat Allah SWT dengan yakin melalui penyaksian (musyāhadah), perasaan (żauqiyah) dan mata hati (bașìrah).

Berbicara saluran ilmu ladunni, Rāji abdul Hamīd al-Kurdi dalam Nazariyah Ma'rifat Bainal Qur'ān wal Falsafah menyebutkan bahwa saluran ilmu ladunni itu ada empat, yaitu hati (al-qalbun), mata hati (al-bașìrah), al-hadasं, dan ilham.

Pertama, hati (al-qalbun). Dalam bahasa al-Qur'ān kata al-qalbun memiliki dimensi sebuah tempat pengajaran, kasih sayang, takut dan keimanan. Oleh sebab itu cakupan terma al-qalbun hanya memuat kondisi yang disadari oleh pemiliknya. ${ }^{29}$ Dalam ranah tasawuf, hati memiliki tujuh tingkat nama yang sekaligus menunjukan fungsi dan cara meningkatkan potensinya, yaitu ${ }^{30}$ as-sadrun ${ }^{31}$, al-qalbun ${ }^{32}$, as-Syagaf33, al-Fu'ad34, mahabbatul qalbi35, as-Suwayda'36, dan mahajjatul qalbi37.

\footnotetext{
${ }^{29}$ Muhammad Quraish Shihab, Wawasan al-Qur'ān (Bandung: Mizan, 1998), 137.

30 Ali Ahmad Isma‘īl, Falsafatut Tasawuf wad Da 'wah Ilallah. (Qohiroh: Itarok, 2002), 357-60.

31 as-Șadrun adalah hati yang berbentuk daging di sebelah kiri dada manusia. al-Qalbun dalam tingkatan ini berfungsi sebagai tempat Islam (ma'din jawharil Islam). Adapun cara meningkatkan potensi al-qalbun level pertama ini adalah dengan bertobat dari semua perbuatan dosa, baik yang jelas atau samar.

32 al-Qalbun adalah tempat bersemayamnya iman dan cahaya akal (nurul 'aqli). Adapun cara meningkatkan potensi al-qalbun level kedua ini adalah dengan penyucian jiwa (nafsun) dari berbagai sifat tercela.

${ }^{33}$ as-Syagaf adalah tempat bersemayamnya cinta kasih dan budi. Adapun cara meningkatkan potensi al-qalbun level ketiga ini adalah dengan menghias al-qalbun dengan sifat terpuji.

34 al-Fu'ad adalah sumber musyahadah dan kebenaran. Adapun cara meningkatkan potensi al-qalbun level keempat ini adalah menghiasi hati dengan berbagai olah spiritual dan hakikat ketuhanan (al-haqā 'iq al-gaibiyah).

${ }^{35}$ Mahabbatul qalbi adalah sumber cinta kepada Allah swt. (hadrah al-ulūhiyah). Adapun cara meningkatkan potensi al-qalbun level kelima ini adalah dengan memproses al-qalbun agar bisa melihat penampakan-penampakan kebenaran hakiki yang bersumber dari Tuhan (tajalliyātul ilähiyah). 36 as-Suwayda' adalah sumber ilmu mukāsyafah, ilmu ladunni, hikmah, rahasia-rahasia (al-asrārur ilāhiyah), dan ilmu nama (ilmul asmá'). Adapun cara meningkatkan potensi al-qalbun level keenam tersebut adalah dengan mengosongkan hati dari selain al-haq, menjaga dengan konsisten sopan santun (adab, dan mematuhi semua perintah nabi dan kekasih-kekasih Allah
} 


\section{Yulianto}

Kedua, mata hati atau hati nurani (al-bașîrah). Secara etimologi kata al-bașìrah bermakna argumentasi dan benar. ${ }^{38}$ Sedangkan secara terminologi al-bașīrah berarti cahaya hati yang dengannya hati bisa melihat sesuatu dengan jelas. ${ }^{39}$ Menurut M. Qurais Shihab term al-bașirah memiliki dua arti, yaitu pertama, bukti yang menjadikan segala sesuatu terlihat sebagaimana adanya dan kedua, proses rasionalisasi yang yang menjadikan objek penalaran menjadi jelas. ${ }^{40}$

Ketiga, kognisi-Intuisi (al-Hadasं). Menurut Fischbein sebagaimana dikutip Budi Usodo, kognisi-intuisi (al-hadasं) dikategorikan menjadi dua, yaitu: intuisi afirmatori (affirmatory intuition) dan intuisi antisipatori (anticipatory intuition). Intuisi afirmatori dapat berupa pernyataan, representasi, interpretasi, solusi yang secara individual dapat diterima secara langsung, self evident, global dan cukup secara intrinsik. Sedangkan intuisi antisipatori adalah intuisi yang muncul ketika seseorang bekerja keras untuk memecahkan masalah, namun solusinya tidak segera diperoleh (tidak secara langsung). Karakteristik intuisi antisipatori adalah sebagai berikut: (1) intuisi tersebut menyajikan ide global; (2) intuisi tersebut bertentangan dengan dugaan pada umumnya, dan (3) intuisi ini berasosiasi dengan perasaan akan kebenaran, meskipun

\footnotetext{
${ }^{37}$ Mahajjatul qalbi adalah sumber manifestasi sifat-sifat Allah. Adapun cara meningkatkan potensi alqalbun level ketujuh tersebut adalah dengan menjaga kesetabilan hati dalam melakukan keenam etape al-qalbun yang telah disebut sebelumnya

${ }^{38}$ Louis Ma'luf, Al-Munjid fi> Al-Lughah Wa Al- A'la>m (Beirut: Da>r Al- Masyriq., 2005), 40.

${ }^{39}$ Abu al-Qāsim Muhammad bin 'Umar Az-Zamakhsyarī, al-Kasyāf, tafsir Surat al-Qoṣos: 43

(Maktabah Syāmilah al-Iṣdāa al-sāni), hlm. 390, Al-Kasyāf' 'an Haqāiq Gawāmiḍ at-Tanzìl wa "Uyūn alAqāwil fi Wujūh at-Ta"wìl (Riyadh: Maktabah al-'Abīkāl, 1998), 390.

${ }^{40}$ Muhammad Quraish Shihab, Tafsir al-Mishbah (Ciputat: Lentera Hati, 2011), 104-5.
} 


\section{Ilmu Ladunni Dalam Perspektif Pendidikan Islam; Telaah Atas Pemikiran Abu Hamid Al-Ghazali}

pembenaran secara rinci atau bukti belum ditemukan. ${ }^{41}$ Masih menurut Fischbein, karakteristik intuisi-kognisi tersebut di atas sadalah sebagai berikut; (1) Kognisi langsung, kognisi self evident (Direct, self evident cognitions). Makna dari karakter tersebut adalah bahwa intuisi adalah kognisi yang diterima sebagai feeling individual tanpa membutuhkan pengecekan dan pembuktian lebih lanjut. (2) Intrinsic certainty. Kepastian kognisi intuisi biasanya dihubungkan dengan perasaan tertentu akan kepastian intrinsik. (3), Coerciveness. Intuisi mempunyai sifat menggiring kearah sesuatu yang diyakini. Hal ini berarti bahwa individu cenderung menolak interpretasi alternatif yang akan mengkontradiksi intuisinya. (4), Extrapolativeness.

Sifat penting kognisi intuitif adalah kemampuan untuk meramalkan di balik suatu pendukung empiris. (5), Globality. Intuisi adalah kognisi global yang berlawanan dengan kognisi yang diperoleh secara logis, berurutan dan secara analitis. ${ }^{42}$

Keempat, Ilham. Ilham adalah pengetahuan yang diberikan kepada seorang hamba, yang bersifat temporer, cepat hilang, pencerahan atas sesuatu yang belum diketahuinya, dan ukuran keberannya adalah relatif artinya bisa benar di samping juga bisa salah. ${ }^{43}$ Berdasarkan kerelatifan ukuran kebenaran ilham, maka sumber

\footnotetext{
${ }^{41}$ Budi Usodo, "Karakteristik Intuisi Siswa SMA dalam Memecahkan Masalah Matematika Ditinjau dari Kemampuan Matematika dan Perbedaan Gender," in AKSIOMA, Maret 2012, vol. 1, 1 (Metro: Unit Publikasi Ilmiah FKIP Universitas Muhammadiyah Metro, 2012).

42 Usodo, "Karakteristik Intuisi Siswa SMA dalam Memecahkan Masalah Matematika Ditinjau dari Kemampuan Matematika dan Perbedaan Gender," 361.

${ }^{43}$ Muhammad bin Ali bin Muhammad bin Ahmad bin Abdullah al-Hatimi ibnu 'Arabi, al-Futu>ha>t al-Makkiyah (Beirut: al-Futu>ha>t al-Makkiyah., 1998), 361.
} 


\section{Yulianto}

ilham itu dikelompokan menjadi tiga, yaitu: (1) bersumber dari Allah; (2) bersumber dari jin atau setan; dan (3) bersumber dari jiwa dan kembali kepada jiwa itu sendiri. ${ }^{44}$

Sedangkan mengenai pembahasan sumber ilmu ladunni terjadi perbedaan yang mencolok antara kelompok sufi dan filsafat. Kelompok sufi berpendapat bahwa sumber ilmu ladunni adalah berasal dari sumber eksternal manusia walaupun usahanya adalah dari manusia itu sendiri. Menurut mereka sumber eksternal itu adalah Allah swt. Melalui perantara wahyu atau ilham. ${ }^{45}$

Berbeda dengan kelompok sufi, para filsuf berpendapat bahwa sumber ilmu ladunni adalah berada dalam internal manusia itu sendiri, yaitu intuisi dan intelek. Menurut Bergson intuisi adalah naluri yang independen, sadar-diri, mampu merenungkan obyeknya kemudian memperluasnya hingga tanpa batas. Sedangkan intelek adalah fakultas akal yang memiliki kemampuan membentuk ide yang gamblang ketika berbagai ide tersebut mengalami diskontunyuitas dan immobilitas. ${ }^{46}$

\section{Hirarki Ilmu Abu Hamid Al-Ghazali Dalam Perspektif Filsafat}

Dalam perspektif ontologi, Abu Hamid al-Ghazali menerangkan bahwa sesuatu yang diketahui (al-ma'lūm) bisa meningkat menjadi sebuah ilmu (science) adalah ketika objek pengetahuan telah diketahui dengan pasti derajat

\footnotetext{
${ }^{44}$ az-Zubaidi, Mașādirul Ma 'rifah Fi al-Fiker ad-Dìni wa al-Falsafi, 256.

${ }^{45}$ Hamid, Nazāriyah Ma rifat Bainal Qur'ān wal Falsafah, 667.

46 Betrand Russel, History Of Philosophy and Its Connection With Political and Social Circumstances From The Earliest Times to The Present Day, (terj.) Sejarah Filsafat Barat (Yogyakarta: Pustaka Pelajar, 2004), 1032.
} 


\section{Ilmu Ladunni Dalam Perspektif Pendidikan Islam; \\ Telaah Atas Pemikiran Abu Hamid Al-Ghazali}

kekonkretannya (a'yān), kualitasnya (kayfiyah), kuantitasnya (kimiyah), substansinya (jawhar), dan esensinya (żātun).

Sedangkan dalam perspektif epistimologi, ada enam saluran ilmu yang berkembang pada masa Abu Hamid al-Ghazali dalam tradisi keilmuan yang berbeda dan terkadang menjadikan masing-masing ilmu berjarak dan terlihat saling berseberangan. Ke enam saluran ilmu tersebut adalah Al-Qur'ān dan as-Sunnah; panca indera; khabar mutawatir; berpikir dan merenung; rasio (intelegensi); intuisi dan membedakan objek pengetahuan (al-mayzu, distinction). Objek Ilmu dalam perspektif Abu Hamid al-Ghazali adalah sebuah hirarki keilmuan itu sendiri. Sebuah hirarki keilmuan yang terbentang mulai ilmu Tuhan dan ilmu manusia; ilmu teoritis dan praktis; ilmu fardlu a'in dan kifayah; Ilmu religius dan intelektual; dan ilmu yang dihadirkan (huduri/goibi) dan dicapai (kasbun). Dalam berbagai cabang keilmuan, hirarki keilmuan yang tersebut di atas telah mencantumkam daftar berbagai disiplin ilmu yang bisa dipelajari, dikembangkan, dan diajarkan berdasarkan sepuluh objek ilmu. Objek-objek ilmu tersebut yaitu: pertama, kajian tentang eksistensi dzat, penyakit, dan perkara yang nikmat; kedua, kajian tentang kemustahilan berkumpulnya dua hal yang saling berlawanan; ketiga, kajian tentang panca indera; keempat, kajian tentang khobar mutawatir; kelima, kajian tentang fahwal khitāb; keenam, kajian profesi dan teknologi; ketujuh, kajian tentang teori-teori; kedelapan, kajian tentang terutusnya para utusan; kesembilan, kajian tentang mu'jizat; dan kesepuluh, kajian tentang sam 'iyyāt. 


\section{Yulianto}

Dalam aspek aksiologi, makna keterikan ilmu dengan nilai dalam perspektif Abu Hamid al-Ghazali adalah perubahan essensi ilmu yang awalnya bersifat terpuji namun karena terpengaruh faktor eksternal maka menjadi sebaliknya, tercela. Menurut Abu Hamid al-Ghazali ada tiga faktor yang menjadikan perubahan nilai ilmu tersebut, yaitu: pertama, memberi efek negatif kepada pemilik ilmu atau kepada orang lain seperti ilmu sihir; kedua, umumnya mengakibatkan efek negatif kepada pemilik ilmu itu sendiri seperti ilmu perbintangan; dan ketiga, mempelajari ilmu tanpa mengetahui prioritas ilmu yang harus dipelajari (seperti mempelajari yang sulit sebelum yang mudah, yang level tinggi sebelum yang rendah dan seterusnya).

\section{Ilmu Ladunni dalam Perspektif Abu Hamid Al-Ghazali Definisi Ilmu Ladunni}

Secara eksplisit Abu Hamid al-Ghazali mengartikan ilmu ladunni sebagai pancaran cahaya ilham yang terjadi setelah terjadinya kesetabilan emosional, spiritual, dan intelektual seseorang. Pengertian ini memberikan stimulus bahwa di samping ilmu ladunni adalah sebuah produk dari sebuah perjalanan emosional, spiritual, dan intelektual seseorang, yang berupa pancaran kecerdasan (wahbiyah), dia

adalah sebuah eksistensi esotorik yang terkadang tidak bisa dipahami langsung dari substansinya, namun bisa diketahui melalui tanda-tandanya. Sebuah tanda berupa kesetabilan emosional, spiritual, dan intelektual seseorang dalam menjalani proses kehidupan. 


\section{Ilmu Ladunni Dalam Perspektif Pendidikan Islam; \\ Telaah Atas Pemikiran Abu Hamid Al-Ghazali}

Dalam kerangka berpikir Abu Hamid Al-Ghazali ada tiga hal fundamental dalam memahami eksistensi ilmu ladunni, yaitu cahaya (nūr), intuisi (ilhām, intuition), dan kestabilan (taswiyah). Tiga peristilahan pokok dalam menguak rahasia hakikat, poses memperoleh (metodologi), dan objek yang mendapat pancaran ilmu ladunni, yang sekaligus menjadi subjek pemegang ilmu ladunni yang telah diberikan kepadanya.

\section{Dasar Pijakan Ilmu Ladunni}

Dalam menguatkan kerangka berpikirnya tentang ilmu ladunni, Abu Hamid al-Ghazali menjustifikasi eksistensi ilmu ladunni dengan dua argumentasi, yaitu dengan argumentasi normatif, dan argumentasi eksperimen-spritual. Dalam argumentasi normatif berdasarkan al-Qur'ān setidaknya ada lima ayat kitab suci yang dijadikan Abu Hamid al-Ghazali sebagai dasar eksisitensi ilmu ladunni. Beberapa ayat kalamulläh yang dijabarkan dari pengertian kata 'allama sebagaimana terdapat dalam Q.S an-Nisā': 113 dan Q.S an-Najmu:5

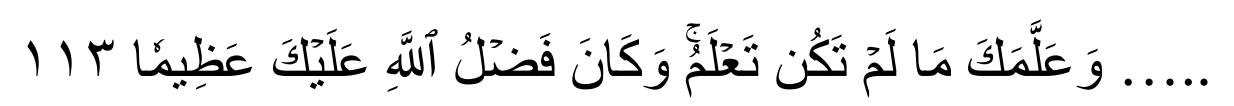

Artinya: Dan telah mengajarkan kepadamu apa yang belum kamu ketahui.

Dan adalah karunia Allah sangat besar atasmu. ${ }^{47}$

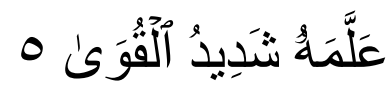

Artinya: Yang diajarkan kepadanya oleh (Jibril) yang sangat kuat. ${ }^{48}$

\footnotetext{
47, Yayasan Penyelenggara dan Penterjemah/Penafsiran Al-Qur'an, Al-Qur'an dan Terjemahan (Jakarta: Departeman Agama Republik Indonesia, 1978), QS. an-Nisa'(4): 113.

48 , Yayasan Penyelenggara dan Penterjemah/Penafsiran Al-Qur'an, Al-Qur'an dan Terjemahan, QS. anNajm (53): 5.
} 


\section{Yulianto}

Dalam kedua ayat suci tersebut di atas, terkandung sebuah pengertian adanya sebuah eksistensi produk keilmuan yang bersumber dari alam metafisika (ilāhiyah). Sebuah ilmu pengetahuan yang langsung diajarkan Tuhan kepada seorang hamba tanpa perantara sebagai bentuk karunia (al-fadlu) dan kasih sayang (ar-rahmah) kepada hamba-Nya; atau di ajarkan kepada seorang hamba melalui perantara seorang malaikat.

Secara eksplisit dalam kedua ayat tersebut, subjek dari pemberi ilmu adalah Allah swt dan malaikat Jibril as. Sedangkan Rasulullah saw, adalah penerima ilmu yang dalam surat an-Nisā' di atas disebut dengan mukhātab (orang yang sedang diajak berbica oleh Allah SWT) dan șāhibukum (sahabat). Artinya, Rasulullah saw, selalu mengharapkan kebaikan bagi sahabatnya sebagaimana tertera dalam surat anNajmu.

Rasulullah SAW adalah orang yang menerima pengajaran dari Tuhan yag trasedental dan malaikat yang bersifat metafisika (gaib). Penggunaan kata ganti orang kedua sebagai panggilan dan kata sahabat memberikan isyarah adanya persyaratan kedekatan (al-qurbu) antara penerima ilmu dan yang memberikan pengajaran. Sebuah kedekatan spiritual yang menghubungkan alam atas ('ālamul a'lā) dengan alam bawah ('ālamus suflā) sebagaimana keterangan Abu Hamid al-Ghazali.

Ketika proses kedekatan melahirkan pengajaran, maka dalam tiga ayat selanjutnya, yakni Q.S al-Ankabut (29): 9, Q.S at-Talak (65): 2-3, dan Q.S al-Anfal (8): 29, Allah swt menjelaskan bahwa dalam dalam berbagai dimensi kehidupan, proses 


\section{Ilmu Ladunni Dalam Perspektif Pendidikan Islam; Telaah Atas Pemikiran Abu Hamid Al-Ghazali}

perjuangan mengendalikan hawa nafsu (riyādatu wa mujāhadatun nafsi) dan mempertahankan kualitas ketakwaan (taqwā) akan membentuk sebuah kecerdasan emosional dan spiritual. Kedua kecerdasan tersebut membuka pancaran cahaya petunjuk (nūrul hidāyah) dalam setiap perkembangan kualitas dan kuantitas jiwa manusia, Serta cahaya spiritual sebagai sumber kekuatan beragama dan kunci pengurai problem kehidupan (nūrul furqān).

Argumentasi eksistensi ilmu ladunni yang kedua menurut Abu Hamid alGhazali adalah eksistensi ilmu ladunni itu sendiri. Sebuah eksistensi yang terpersonafikasikan di dalam jiwa seseorang yang telah berhasil menerapkan metodologi pencapaian ilmu ladunni dalam kehidupannya. Hal ini tersirat dalam dua pernyataan berikut;

"Padangan seorang mukmin adalah dengan cahaya Allah (nürilläh) yang terletak dibelakang tirai yang sangat halus. Cahaya itu benar-benar nyata. Sebuah cahaya yang disorotkan Allah kedalam hati orang yang beriman dan ditampakkan dalam tutur kata mereka."

"Ilmu itu ada dua macam. Salah satunya adalah ilmu batin yang terletak di dalam hati. Itulah ilmu yang bermanfaat. Sebagian ulama ditanya tentang hakikat ilmu batin, apakah ilmu tersebut? Dia menjawab: ilmu batin adalah rahasia Allah yang diletakkan di dalam hati para kekasihnya. Ilmu yang tidak diketahui oleh malaikat dan manusia."

Dalam kedua pernyataan di atas disebutkan bahwa sebuah ilmu yang bermanifestasi dalam bentuk cahaya dan rahasia (nūrullāh wa asrārullāh) adalah sebuah ilmu yang diberikan Allah kepada hamba-Nya yang beriman (mu'min) dan para kekasih-Nya (waliyyullāh). Dua derajat seorang hamba di hadapan Tuhannya, 


\section{Yulianto}

yang hanya diperoleh setelah perjuangan berproses dalam keilmuan (al-'ilmu), keimanan (al-ìmān), dan amal salih (al-'amaluṣ șālih).

a. Kajian Cahaya (Nür) Dan Korelasinya Dengan Potensi Manusia Dalam Kesiapannya Memperoleh Ilmu Ladunni

1) Perbedaan identitas cahaya dan implikasinya dalam epistimologi ilmu

Dalam kerangka berpikir Abu Hamid al-Ghazali term cahaya (nūr) memiliki dua arti, yaitu arti (1) hakiki (truth) dan (2) majazi (metafora).

a) Cahaya hakiki

Cahaya dengan makna hakiki adalah hak priogratif Tuhan Yang Maha Absolut. Sebuah hak paten personaliti yang tidak boleh dan tidak akan bisa dimiliki oleh selain-Nya. Karena sesungguhnya Dialah Sang Maha Cahaya itu sendiri.

Dalam proses belajar, khususnya tentang teori kecerdasan, maka emanasi Tuhan -cahaya hakiki- kedalam potensi manusia yang berupa cahaya dalam bentuk metafora adalah asal-usul dari semua dimensi kecerdasan manusia.

b) Cahaya majazi (metafora)

Cahaya metafora adalah sebuah sebutan bagi tiga eksistensi potensi manusia. Tiga potensi manusia, yang oleh Abu Hamid al- 


\section{Ilmu Ladunni Dalam Perspektif Pendidikan Islam; \\ Telaah Atas Pemikiran Abu Hamid Al-Ghazali}

Ghazali disebut sebagai alat persepsi (alātul idrāk) dalam diri manusia. Tiga alat persepsi yang dalam bahasa saluran ilmu terkenal dengan bahasa akal ('aqlun, intelligence), roh (rüh, spirit), dan jiwa (nafsun).

\section{2) Relasi Cahaya Metafora Dengan Potensi Manusia Dalam Menerima} Ilmu Ladunni

Di samping menjadi saluran ilmu, cahaya metafora dalam diri manusia juga menjadi sumber (1) inspirasi, (2) motifasi, (3) imajinasi, (4) fantasi, (5) persepsi, (6) pencerapan, (7) perekam, (7) motorik, dan (8) intuitif.

\section{a) Akal ('Aqlun, Intelligence)}

Dalam pemikiran Abu Hamid al-Ghazali salah satu cara untuk memperoleh ilmu ladunni adalah dengan mere-aktikan dan mere-aktualisasikan potensi akal dengan maksimal. Karena dalam potensi akal terdapat kekuatan metafisika yang mampu menghubungkan alam fisik, material, dan rendah ini dengan alam metafisika, non-material, dan alam atas tempat berbagai pengetahuan berasal.Sebuah potensi tertinggi akal yang dalam istilah Abu Hamid al-Ghazali popular dengan sebutan akal aktif (intelligence active, 'aqlul fa 'âl). 


\section{b) $\operatorname{Roh}(\operatorname{Ru} h$, Spirit)}

Keunikan pembahasan Abu Hamid al-Ghazali tentang roh spiritual adalah relasinya yang sangat erat dengan kecerdasan intelektual yang menjadi tugas fakultas akal spiritual. Perumpamaan roh spiritual bagi kelangsungan akal spiritual dalam menyokong berbagai potensi fakultas akal adalah ibarat sebuah penyuplai stamina bagi aktifitas sebuah gerakan.

\section{c) Jiwa (nafsun)}

(1) Hakikat Jiwa (nafsun)

Sebagaimana kajian tentang akal dan roh, Abu Hamid alGhazali juga mendefinisikan Jiwa (nafsun) sebagai sebuah lațīfah. Karena substansi jiwa adalah sebagai sebuah lațifah, maka tidak heran jika dalam berbagai pendapatnya, Abu Hamid al-Ghazali menyatakan bahwa jiwa manusia yang bisa mengfungsikan potensi lahiriahnya -yang berupa kemampuan (1) mengingat (reminiscence, tażakkur), (2) menghapal (tahaffud), (3) berpikir (thinker, tafakkur), (4) membedakan (distinction, tamyiz), (5) menimbang berbagai dorongan dari jiwa (deliberation, ruwiyyah), dan (6) menerima berbagai ilmu, dan memotret gambar (form, șuwār) yang tidak bermaterial- adalah jiwa yang tenang (muțainnah), dan berpikir (nātiqah).

(2) Gradasi potensi Jiwa (nafsun) 


\section{Ilmu Ladunni Dalam Perspektif Pendidikan Islam; \\ Telaah Atas Pemikiran Abu Hamid Al-Ghazali}

Dalam membahas tetang gradasi potensi jiwa, Abu Hamid al-Ghazali membaginya menjadi dua bagian, yaitu (1) potensi alamiah (al-quwwatul fitriyyah), dan (2) potensi pengaruh faktor eksternal (al-quwwatut ta 'sìriyah) sebagaimana di bawah ini:

(1) Potensi alamiah (al-quwwatul fitriyyah)

Secara alamiah jiwa manusia menurut Abu Hamid alGhazali memiliki dua potensi fundamental, yaitu (1) potensi berpersepsi (al-quwwatulmudrikah, perception, kognition), dan (2) potensi motorik (al-quwwatul muharrikah).

(2) Potensi pengaruh faktor eksternal (al-quwwatut ta ‘̀ìriyah)

Gradasi Jiwa (nafsun) berdasarkan sudut pandang terpengaruh dan berubah-rubahnya psikologi Jiwa (nafsun) karena berbagai faktor yang mempengaruhinya di bedakan menjadi tiga bagian sebagaimana di bawah ini:

(a) Nafsu tenang (Nafsul Muțmainnah)

(b) Nafsul Lawwāmah

(c) Nafsu yang mendorong kepada kejelekan (Nafsul Ammārah bis $\left.S \bar{u}^{\prime}\right)$

(3) Relasi jiwa (nafsun) dengan alam metafisik ('alāmul goib wa 'alāmul a 'lā) 
Dalam membahas tentang kecenderungan jiwa, Abu Hamid al-Ghazali menyebutkan adanya relasi antara jiwa manusia dengan alam, baik alam fisik-materialis atau alam metafisik. Pendapat tersebut berpijak pada kerangka berpikir Abu Hamid al-Ghazali bahwa jiwa manusia adalah personifikasi dari mikro kosmos sedangkan alam raya adalah makro kosmos.

Berdasarkan relasi tersebut, menurut Abu Hamid alGhazali, cermin jiwa manusia akan semakin kabur dan tidak objektif ketika terlalu berlebihan berhubungan apalagi menjadikan fokus relasinya hanya dengan alam fisik-materialis ('ālamus suflà). Sebaliknya jika fokus relasi cermin jiwa manusia selalu tertuju kepada alam atas ('alāmul a lāa), sebuah alam tempat berasal semua ilmu pengetahuan, maka jiwa manusia akan semakin mudah menyerap berbagai ilmu dari sumbernya langsung. Bahkan relasi tersebut akan menjadikannya bisa berhubungan langsung dengan akal aktif (intelligence active, 'aqlul fa ‘ăl) yang berimplikasi merubah kedudukan jiwa yang awalnya hanya sebagai pencari dan penerima ilmu pengetahuan menjadi sumber ilmu pengetahuan itu sendiri (manba'ul 'ilmi).

\section{b. Epistimologi Ilmu Ladunni}

\section{1) Saluran Ilmu ladunni (Ṭāriqatul 'Ilmil Ladunni)}




\section{Ilmu Ladunni Dalam Perspektif Pendidikan Islam; \\ Telaah Atas Pemikiran Abu Hamid Al-Ghazali}

Dalam kerangka pemikiran Abu Hamid al-Ghazali ada tiga saluran ilmu yang menjadi alat untuk memperoleh ilmu ladunni, yaitu (1) hati spiritual (al-qalbu, heart), (2) ilham (ilhäm, intuition), dan (3) wahyu (revelation).

\section{a) Hati spiritual (al-qalbu, heart)}

Pembahasan tentang saluran ilmu ladunni dalam perspektif Abu Hamid al-Ghazali terlihat sangat unik.Unik karena Abu Hamid alGhazali menjadikan hati spiritual (al-qalbu, heart) sebagai salah satu saluran ilmu ladunni.

Dalam membahas tentang hati spiritual yang berfungsi sebagai saluran ilmu, Abu Hamid al-Ghazali menerangkan dengan panjang lebar dimensi hati tersebut sebagaimana di bawah ini:

(1) Substansi hati spiritual

Menurut Abu Hamid al-Ghazali substansi hati spiritual adalah sebuah latîifah robbāniyah rūhāniyah. Sebagai sebuah lațîfah, hati spiritual memiliki beberapa keistimewaan, yaitu bagian eksistensi manusia (1) yang ber-persepsi dan ber-kognisi (al-mudrik), (2) ber-intelektual (al-alim), (3) ber-metafisika (al-ārif), (4) yang terkena khitob sariat (al-mukhätab), (5) tersiksa karena terhalang dari berbagai potensi lahiriahnya sebab berbagai kotoran dan karatan 
dosa (al-mu'äkab), dan (6) yang tercela karena jauh dari tujuan awal penciptaannya (al-mu'ātab).

Berdasarkan substansi hati spiritual di atas, maka dapat tidak heran jika dia disifati dengan kata robbāniyah rūhāniyah. Karena makna sifat robbāniyah bagi hati spiritual adalah potensi lahiriahnya memiliki karakter Tuhan yang berupa kemampuan (1) berintelektual, (2) berkognisi, dan (3) bermetafisika. Sedangkan makna dari penyifatannya dengan kata rūhāniyah adalah potensi lahiriah hati spiritual untuk berelasi, berkomunikasi, dan belajar dari alam metafisika ('âlāmul goib) dan berbagai mediator ilmu pengetahuan berupa makhluk rūhāni (spiritual) seperti malaikat, rijālul gaib, ruh para nabi, orang-orang salih, dan para kekasih Tuhan yang telah meninggal di samping dia juga mampu mengambil ilmu dari sumbernya yang utama, lauh mahfudz, akal aktif (intelligence active, 'aqlul fa 'āl).

(2) Hati spiritual sebagai tempat bersemayamnya ilmu dan sumber pencerahan

Pengertian hati spiritual sebagai sumber pencerahan adalah karena potensinya sebagai tempat bersemayam para malaikat yang mereka adalah makhluk yang tercipta dari cahaya. Sebuah eksistensi makhluk Tuhan yang menjadi sumber inspirasi, 


\section{Ilmu Ladunni Dalam Perspektif Pendidikan Islam; \\ Telaah Atas Pemikiran Abu Hamid Al-Ghazali}

motifasi, dan motorik semua pemikiran dan perbuatan posistif manusia.

Keistimewaan hati spiritual di atas, adalah karena posisinya dalam alam spirit adalah laksana sebuah cermin yang memantulkan berbagai pengetahuan yang telah tertulis di lauh mahfudz. Karena substansi hati spiritual dalam menangkap, menahan, dan memantulkan kembali berbagai pengetahuan dari lauh mahfudz adalah ibarat sebuah cermin, maka potensinya yang begitu menakjubkan tersebut -menurut Abu Hamid al-Ghazalitidak bisa berfungsi dengan maksimal tau bahkan tidak berfungsi sama sekali adalah karena terkena salah satu dari lima faktor di bawah ini, baik faktor internal atau eksternal cermin itu sendiri sebagaimana berikut:

(a) Rusaknya bayangan.

(b) Cermin tersebut kotor dan berkarat.

(c) Posisi bayangan yang menyimpang dari arah cermin seperti ketika benda dari bayangan tersebut berada di belakang cermin.

(d) Terdapat tabir di antara cermin dan sumber bayangan.

(e) Karena ketidak tahuan akan posisi di mana terdapat bayangan.

\section{b) Wahyu (revelation)}


Menurut Abu Hamid al-Ghazali berbagai pencerahan, pemahaman, dan isyarah yang terjadi dalam fakultas hati dan akal adalah bersumber dari wahyu.

Alur kerangka berpikir fungsi wahyu sebagaiman tersebut di atas, menurut Abu Hamid al-Ghazali adalah sebagaimana di bawah ini:

(1) Kesucian spiritual (rūhul qudsi) sehingga maka dia menghadapkan dirinya kepada Tuhannya dengan bersandar kepada emanasi dan pancaran karunia-Nya.

(2) Tuhan menerima jiwa suci tersebut lalu menjadikannya lembaranlembaran (lawhun) dan menjadikan jiwa universal (nafsul kulli) sebagai pena (al-qolam) yang melukis berbagai ilmu dalam jiwa itu sendiri.

\section{c) Ilham (Ilhām, Intuition)}

Dalam pemikiran Abu Hamid al-Ghazali, ilham (ithām, intuition) adalah eksitasi jiwa universal (tanbihun nafsil kulliyah) pada jiwa parsial manusia berdasarkan kesucian (at-tazkiyah), resepsi (al$i d r \bar{a} k)$, dan daya kesiapannya (al-isti $` a \bar{d} d)$.

Ilham (ilhām, intuition) sebagai salah satu saluran ilmu pengetahuan menurut Abu Hamid al-Ghazali memiliki kemampuan revolusioner. Dikatakan revolusioner karena dia berfungsi sebagai pencerahan dan pemecahan sebuah fenomena (problem solving). 


\section{Ilmu Ladunni Dalam Perspektif Pendidikan Islam; \\ Telaah Atas Pemikiran Abu Hamid Al-Ghazali}

\section{2) Metode Mendapatkan Ilmu Ladunni}

Dalam kerangka pemikiran Abu Hamid al-Ghazali, ada tiga metode pokok untuk memperoleh ilmu ladunni. Dua metode pertama bersumber dari internal manusia, yaitu (1) belajar dan berpikir menggunakan rasio, dan (2) riyādah serta mujāhadah menggunakan perpaduan rasio dan hati. Sedangkan satu metode terakhir bersumber dari sumber eksternal manusia, yaitu menjaga kualitas dan kuantitas makanan.

Dua metode pertama ibarat sebuah bola lampu sedangkan satu metode terakhir adalah ibarat listrik yang menjadi sumber daya berpijarnya bola lampu.

\section{a) Belajar Dan Berpikir Serta Relasinya Dengan Kecerdasan}

\section{Intelektual (IQ)}

Belajar dan berpikir adalah dua aktifitas akal yang berhubungan dengan kecerdasan otak manusia untuk menghasilkan sebuah produk pemikiran yang dinamakan pengetahun. Dikatakan sebagai aktifitas akal karena keduanya berposisi sebagai fungsi fakultas akal.

Jika belajar adalah proses eksplorasi sesuatu dari sebuah potensi (al-quwwah) menjadi aktual (al-fali), maka berpikir adalah usaha jiwa makro dalam menyerap suatu pengetahuan. Re-aktifikasi 
jiwa makro -menurut Abu Hamid al-Ghazali-, memberikan produk pengetahuan yang lebih mendalam dan fenomenal dari pada belajar dari faktor eksternal yang tercitrakan dalam belajar para ilmuan dan intelektual.

b) Riyādah, Mujāhadah, dan Sabar Serta Relasinya Dengan Kecerdasan Emosional (EQ)

Sebagai trilogi metode melatih, membiasakan, dan mendidik jiwa untuk mencapai potensi positif terbaiknya, proses riyādah, mujähadah, dan sabar dalam perspektif kecerdasan sangat erat hubungannya dengan kecerdasan emosional (EQ). Karena dengan riyādah yang dilakukan dengan sungguh-sungguh, kontinyu, dan penuh kesabaran seseorang akan memperoleh jiwa sepritual yang tenang, semangat yang menggelora, optimis, dan tidak mudah putus asa.

Ibarat sebuah mesin otomatis dengan proses riyādah, mujāhadah, dan sabar, jiwa seseorang akan menjadi terlatih, peka, rensponsif, dan revormer serta mudah menangkap pantulan-pntulan pengetahuan dari sumbernya, yaitu lauh mahfudz.

c) Menjaga Kualitas Dan Kuantitas Makanan Serta Relasinya Dengan Kecerdasan Spiritual (SQ) 


\section{Ilmu Ladunni Dalam Perspektif Pendidikan Islam; \\ Telaah Atas Pemikiran Abu Hamid Al-Ghazali}

Sebagai pelaku sepritual sekaligus tokoh akdemisi, Abu Hamid al-Ghazali memiki pandangan yang sangat unik tentang pengaruh kualitas dan kuantitas makanan, baik yang halal, syubhat, apalagi yang haram dalam pembentukan sepritualitas seseorang. Sebuah kecerdasan yang muncul dari emanasi pencerahan cahaya Tuhan kedalam relung-relung spiritualitas para pengosumsi makanan halal.

Dalam berbagai ayat, sabda Rasulullah saw, dan komentar para spiritualis yang dijadikan rujukan Abu Hamid al-Ghazali sebagai sumber kecerdasan berbasis pancaran dapat kita hipotesakan bahwa makanan yang terjamin kualitas dan kuantitas kehalalannya adalah sumber dari dua kecerdasan yang lain, yaitu kecerdasan intelektual dan emosional.

\section{3) Kontribusi Konsep Ilmu Ladunni Terhadap Pendidikan Islam}

Bersadarkan berbagai keterangan dalam poin A yang menjelaskan ilmu secara umum dalam perspektif Abu Hamid al-Ghazali dan Poin B yang menjelaskan ontologi dan epistimologi ilmu ladunni dalam perspektif Abu Hamid al-Ghazali, maka kontribusi ilmu ladunni terhadap pendidikan Islam adalah terletak pada kedua dimensi tersebut, yaitu dimensi ontologi dan epistimologi.

\section{a) Dimensi Ontologi}


Ilmu Ladunni sebagai sebuah produk olah spiritual, intelektual, dan emosional berupa penyingkapan, pemecahan, dan pencerahan sebuah atau berbagai permasalahan atau keilmuan sangat berkontribusi dalam terumuskannya tujuan pendidikan Islam. Kontribusi tersebut terletak pada ke-komprehensipan tujuan pendidikan Islam yang berupa pembentukan individu berkepribadian utuh jasmani dan rohani, fisik dan psikologis serta mental dan spiritual yang mampu hidup dengan wajar dan normal berdasarkan ketakwaannya kepada Allah SWT (insān kāmil).

\section{b) Dimensi Epistimologi}

Dalam dimensi epistimologi, ilmu ladunni dalam perspektif Abu Hamid al-Ghazali memiliki kontribususi yang nyata dalam dua hal, yaitu (1) saluran ilmu yang berupa hati spiritual dan Ilham, dan (2) metode mendapatkan ilmu yang berupa (a) belajar robbani dan (b) menjaga kualitas dan kuantitas makanan.

\section{a. Posisi Ilmu Ladunni Dalam Kerangka Hirarki Ilmu Abu Hamid Al-} Ghazali

Berdasarkan pengertian bahwa ilmu ladunni adalah sebuah ilmu yang menjadi produk dari pancaran ilham kedalam jiwa yang telah stabil, maka dapat dimengerti bahwa dalam kerangka hirarki keilmuan yang 


\section{Ilmu Ladunni Dalam Perspektif Pendidikan Islam; \\ Telaah Atas Pemikiran Abu Hamid Al-Ghazali}

ditawarkan Abu Hamid al-Ghazali, ilmu ladunni bertempat pada posisi yang sangat unik.

Pengertian ilmu ladunni sebagai produk pemberian Tuhan atas usaha manusia menjadikan ilmu ladunni menempati sebuah posisi yang unik dalam hirarki keilmuan Abu Hamid al-Ghazali sebagaimana di bawah ini:

1) Ilmu ladunni berada dalam cakupan ilmu yang dihadirkan.

2) Ilmu ladunni berada dalam cakupan semua hirarki keilmuan Abu Hamid al-Ghazali.

Implikasi karakter ilmu ladunni sebagai produk mengharuskan adanya sebuah metodologi yang tersistem dalam memproduknya. Sebuah metodologi berupa formulasi khusus yang bisa disinergikan dalam berbagai metodologi disiplin keilmuan sebagaimana dalam keterangan metodologi meraih ilmu ladunni dalam penjelasan yang akan datang.

\section{A. Kesimpulan}

Berdasarkan hasil penelitian yang telah dilakukan dan telah dipaparkan sebelumnya, maka dapat disimpulkan bahwa: 


\section{Yulianto}

1. Definisi ilmu ladunni menurut Abu Hamid al-Ghazali adalah pancaran cahaya ilham yang terjadi setelah terwujudnya kestabilan emosional, spiritual, dan intelektual seseorang.

2. Ilmu ladunni dalam perspektif Abu Hamid al-Gazali memiliki dua dimensi, yaitu dimensi terbatas dan dimensi tidak terbatas.

1) Dimensi terbatas. Maksud dari keterbatasan dimensi ilmu ladunni adalah berdasarkan sudut pandang bahwa dia adalah sebuah produk dari bagian ilmu yang dihadirkan (huḍūri). Namun walaupun ilmu ladunni dalam pemikiran Abu Hamid al-Ghazali adalah hanya sebuah produk, tapi dia memiliki peran yang sangat vital dalam memberikan pencerahan, pemahaman, dan pemecahan berbagai masalah dalam pembelajaran (problem solving).

2) Dimensi tidak terbatas. Maksud dari ketidak terbatasan dimensi jelajah ilmu ladunni adalah sifat pencerahan, pemahaman, dan pemecahan yang dimilikinya terhadap berbagai permasalah yang awalnya bersumber dari sebuah emanasi terhadap sisi spiritualitas manusia merambah kesemua dimensi hirarki keilmuan sebagaimana diterangkan Abu Hamid al-Ghazali.

3. Metode yang ditawarkan Abu Hamid al-Ghazali untuk memperoleh ilmu ladunni adalah:

a. Belajar dan berpikir untuk memperoleh emanasi hakiki berupa kecerdasan intelektual (IQ) melalui akal spiritual. 


\section{Ilmu Ladunni Dalam Perspektif Pendidikan Islam; \\ Telaah Atas Pemikiran Abu Hamid Al-Ghazali}

b. Riyādah, Mujāhadah, dan sabar untuk menginstalasi kecerdasan emosional (EQ) yang bersumber dari kejernihan cermin hati dan kesucia jiwa.

c. Mengosumsi makan yang halal untuk menyetimulus berbagai kecerdasan, intelektual dan emosional lewat kecerdasan spiritual (SQ).

4. Kurikulum yang tepat untuk meraih ilmu ladunni adalah kurikulum humanistik. Alasannya, karena karakter kurikulum humanistik adalah aktualisasi potensi dasar manusia melalui pendidikan. Karakter tersebut sangat sesuai dengan pengertian terbatas ilmu ladunni yang menunjukkan keterbatasannya hanya sebagai produk dari aktualisasi potensi lahiriah manusia. Berbagai potensi lahiriah, yang oleh Abu Hamid al-Ghazali dinyatakan bersumber dari saluran ilmu yang dinamakan secara mutlak sebagai hati spiritual, yaitu potensi lahiriah manusia yang mempunyai substansi sebagai essensi spiritualitas manusia yang bersifat ketuhanan dan sumber berbagai pengetahuan sekaligus cermin penerima pantulan cahaya dari alam metafisika tempat tercatatnya semua ilmu pengetahuan (latîfatur robbāniyatur rūhiyyah).

5. Dalam perspektif ilmu ladunni sebagai produk aktualisasi diri manusia yang terdidik, baik dalam pendidikan insaniyah atau robbaniyah, ilmu ladunni memiliki kontribusi yang nyata terhadap tujuan pendidikan Islam, yaitu mencetak manusia paripurna baik secara fisik atau non-fisik. 


\section{Yulianto}

\section{B. SARAN}

Berdasarkan lima kesimpulan dalam poin kesimpulan dalam penelitian ini, maka ada beberapa saran demi perbaikan konsep ilmu ladunni dalam perspektif Abu Hamid al-Ghazali, yaitu:

1. Hendaknya dilakukan penelitian lebih lanjut dan mendalam tentang konsep ilmu ladunni dalam perspektif Abu Hamid al-Ghazali. Tujuannya adalah untuk semakin menutup berbagai kekurangan dalam penelitian ini.

2. Hendaknya lembaga pendidikan, baik formal yang ingin mencetak peserta didik yang berkualitas secara material dan spiritual menjadikan pendidikan berbasis ketuhanan (tarbiyatur robbāniyah) sebagai penyempurna pendidikan yang selama ini telah berjalan. Sebaliknya pendidikan non-formal yang dalam konteks Negara Republik Indonesia banyak kita temukan dalam citra pendidikan diniyah di pesantren juga mengintegralkan pendidikan berbasis kemanusian (tarbiyatul insāniyah) dalam kurikulum pendidikannya.

3. Hendaknya lembaga pendidikan baik yang formal, non-formal, atau informal menjadikan aktualisasi potensi alamiah peserta didik sebagai basis psikologi desain kurikulum mereka, yaitu sebuah kurikulum yang terkenal dengan nama humanistik.

4. Karena interkoneksi dalam optimalisasi potensi akal, jiwa, roh, dan hati spiritual adalah kunci dari kurikulum humanistik maka bagi para pemegang kebijaknaan pendidikan tidak boleh melakukan diskriminasi dalam proses 


\section{Ilmu Ladunni Dalam Perspektif Pendidikan Islam; \\ Telaah Atas Pemikiran Abu Hamid Al-Ghazali}

optimalisasi keempat potensi alamiah manusia tersebut dalam berbagai rancangan dan desain kurikulum pendidikannya.

5. Hendaknya lembaga pendidikan sangat selektif dalam memilih dan menyajikan kualitas serta kuantitas berbagai menu makanan dan minuman yang diperjual belikan di kantin sekolah.

\section{DAFTAR RUJUKAN}

, Yayasan Penyelenggara, dan Penterjemah/Penafsiran Al-Qur'an. Al-Qur'an dan Terjemahan. Jakarta: Departeman Agama Republik Indonesia, 1978.

'Arabi, Muhammad bin Ali bin Muhammad bin Ahmad bin Abdullah al-Hatimi ibnu. al-Futu>ha>t al-Makkiyah. Beirut: al-Futu>ha>t al-Makkiyah., 1998.

Az-Zamakhsyarī, al-Kasyāf, tafsir Surat al-Qoṣos: 43 (Maktabah Syāmilah al-Iṣdāa alsaāni), hlm. 390, Abu al-Qāsim Muhammad bin 'Umar. Al-Kasyāf'an Haqāiq Gawāmiḍ at-Tanzìl wa "Uyūn al-Aqāwil fi Wujūh at-Ta"wïl. Riyadh: Maktabah al'Abīkāl, 1998.

Barizi, Ahmad. Pendidikan Integratif. Malang: UIN Maliki Press, 2011.

Bukhari, Abi 'Abdillah Ibn Isma'il. Shahìhu-l-Bukhāri. Beirut: Dār al-Kutub al-Ilmiyah, 2005.

Fakhri, Majid. "al-Masyā'iyah al-Qadīmah." In al-Mausū'atul Falsafiyatul Arābiyah, Vol. II. Ma'had al-Inma al-Arābiyah, 1998.

Fayumi, Ahmad bin Muhammad al-. al-Misbāh al-Munīr. Qohiroh: Dar al-Hadits, 2000.

Ghazāli, Abu Hamid al-. Majmū 'ah Rasāil; ar-Risālah Alladuniyah. Maktabah atTaufĪqiyyah, n.d.

Hamid, Raji Abdul. Nazāriyah Ma 'rifat Bainal Qur'ān wal Falsafah. Riyadh: Maktabah al-Muayyad, 1992.

Helwa, ar-Royce Syarel. Mausū 'ah A'lāmul Falsafah. Beirut: Dār al-Kutub al-Ilmiyah, 1992. 


\section{Yulianto}

Isa, Abdul Gholib Ahmad. Mafhūmut Tasawwuf. Beirut: Dār al-Jīl, 1992.

Isma‘īl, Ali Ahmad. Falsafatut Tasawuf wad Da 'wah Ilallah. Qohiroh: Itarok, 2002.

Ismail, Ilyas. True Islam: Moral, Intelektual, Spritual. Jakarta: Mitra Wacana Media, 2013.

Jurjani, Ali Muhammad al-. at-Ta 'rifāt. Jakarta: al-Harāmain, n.d.

Khozin. Jejak-Jejak Pendidikan Islam di Indonesia Rekonstruksi Sejarah Untuk Aksi. Malang: UMM Press, 2006.

Ma'luf, Louis. Al-Munjid fi> Al-Lughah Wa Al-A'la>m. Beirut: Da>r Al- Masyriq., 2005.

Muhaimin. Pengembangan Kurikulum Pendidikan Agama Islam. Jakarta: Raja Grafindo Persada, 2009.

Nata, Abuddin. Pemikiran Para tokoh Pendidikan Islam Seri Kajian Filsafat Pendidikan Islam. Jakarta: Raja Grafindo Persada, 1988.

Nata, Abuddin, dan dkk. Integrasi ilmu Agama \& Ilmu Umum. Jakarta: Raja Grafindo Persada, 2005.

Qanuji, Sadik bin Hasan al-Qanuji, Abajadul 'Ulūmil Wasyīl Marqūm Fī Bayāni Ahwālil 'Ulūm (Bairut: Dārul Kutubil Ilmiyah, 1978),. Abajadul 'Ulūmil Wasyìl Marqūm Fì Bayāni Ahwālil 'Ulūm. Beirut: Dārul Kutub al-Ilmiyah, 1978.

Qomar, Mujammil. Epistemologi Pendidikan Islam: Dari Metode Rasional Hingga Metode Kritik. Jakarta: Erlangga, 2006.

Qutub, Sayyid. Fi Zilal al-Qur 'ān. Vol. VI. Beirut: Dār as-Syurūq, 1992.

Rosidin. Epistimologi Pendidikan Islam. Yogyakarta: Diandra Kreatif, 2013.

Russel, Betrand. History Of Philosophy and Its Connection With Political and Social Circumstances From The Earliest Times to The Present Day, (terj.) Sejarah Filsafat Barat. Yogyakarta: Pustaka Pelajar, 2004.

Salikhin, Muhammad. Filsafat dan Metafisika dalam Islam. Jakarta: Buku Kita, 2008.

Shihab, Muhammad Quraish. Tafsir al-Mishbah. Ciputat: Lentera Hati, 2011.

- - - Wawasan al-Qur'ān. Bandung: Mizan, 1998. 


\section{Ilmu Ladunni Dalam Perspektif Pendidikan Islam; \\ Telaah Atas Pemikiran Abu Hamid Al-Ghazali}

Tafsir, Ahmad. Ilmu Pendidikan Dalam Perspektif Islam. Bandung: Remaja Rosdakarya, 2011.

Uhbiyati, Nur. Ilmu Pendidikan Islam. Bandung: Pustaka Setia, 1999.

Usodo, Budi. “Karakteristik Intuisi Siswa SMA dalam Memecahkan Masalah Matematika Ditinjau dari Kemampuan Matematika dan Perbedaan Gender." In AKSIOMA, Maret 2012. Vol. 1. 1. Metro: Unit Publikasi Ilmiah FKIP Universitas Muhammadiyah Metro, 2012.

Utaybi, Ihsan. Arsip Multaqā ahlil hadis.. Maktabah Syamilah al-Iṣdar aś-Ṡani, n.d.

Zaini, A. Wahid. Dunia Pemikiran Kaum Santri. Yogyakarta: LKPSM, 1999.

Zubaidi, Abdur Rahman bin Zaid az-. Mașādirul Ma 'rifah Fi al-Fiker ad-Dini wa alFalsafi. Riyadh: Maktabah al-Muayyad, 1992.

Zuhairini. Sejarah Penddikan Islam. Jakarta: Bumi Aksara, 1992. 
Yulianto

90 | Dinamika Vol. 2, No. 2, Desember 2017 